\title{
THE IDENTIFICATION OF THE CF (CYSTIC FIBROSIS) GENE \\ Recent Progress and \\ New Research Strategies
}




\section{ADVANCES IN EXPERIMENTAL MEDICINE AND BIOLOGY}

Editorial Board:

NATHAN BACK, State University of New York at Buffalo

IRUN R. COHEN, The Weizmann Institute of Science

DAVID KRITCHEVSKY, Wistar Institute

ABEL LAJTHA, N.S. Kline Institute for Psychiatric Research

RODOLFO PAOLETTI, University of Milan

Recent Volumes in this Series

Volume 284

ENZYMOLOGY AND MOLECULAR BIOLOGY OF CARBONYL METABOLISM 3

Edited by Henry Weiner, Bendicht Wermuth, and David W. Crabb

Volume 285

HYPERCHOLESTEROLEMIA, HYPOCHOLESTEROLEMIA,

HYPERTRIGLYCERIDEMIA, IN VIVO KINETICS

Edited by Claude L. Malmendier, P. Alaupovic, and H. Bryan Brewer, Jr.

Volume 286

TEMPERATURE AND ENVIRONMENTAL EFFECTS ON THE TESTIS

Edited by Adrian W. Zorgniotti

Volume 287

NEURORECEPTOR MECHANISMS IN BRAIN

Edited by Shozo Kito, Tomio Segawa, and Richard W. Olsen

Volume 288

DRUGS OF ABUSE, IMMUNITY, AND IMMUNODEFICIENCY

Edited by H. Friedman

Volume 289

NUTRITIONAL AND TOXICOLOGICAL CONSEQUENCES OF FOOD

PROCESSING

Edited by Mendel Friedman

Volume 290

THE IDENTIFICATION OF THE CF (CYSTIC FIBROSIS) GENE:

Recent Progress and New Research Strategies

Edited by Lap-Chee Tsui, Giovanni Romeo, Rainer Greger, and Sergio Gorini

Volume 291

FUEL HOMEOSTASIS AND THE NERVOUS SYSTEM

Edited by Mladen Vranic, Suad Efendic, and Charles H. Hollenberg

Volume 292

MECHANISMS OF LYMPHOCYTE ACTIVATION AND IMMUNE

REGULATION III

Edited by Sudhir Gupta, William E. Paul, Max D. Cooper, and Ellen V. Rothenberg

A Continuation Order Plan is available for this series. A continuation order will bring delivery of each new volume immediately upon publication. Volumes are billed only upon actual shipment. For further information please contact the publisher. 


\section{THE IDENTIFICATION OF THE CF (CYSTIC FIBROSIS) GENE}

\section{Recent Progress and}

New Research Strategies

Edited by

Lap-Chee Tsui

The Hospital for Sick Children

Toronto, Ontario, Canada

Giovanni Romeo

Istituto Giannina Gaslini

Genoa, Italy

Rainer Greger

Albert-Ludwigs-Universitat

Freiburg, Germany

and

Sergio Gorini

Fondazione Internazionale Menarini

Florence, Italy

Springer Science+Business Media, LLC 


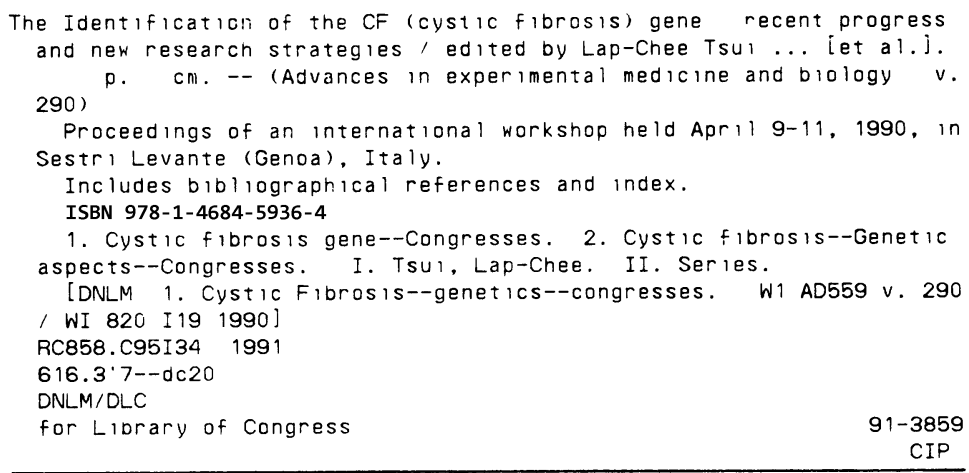

Proceedings of an international workshop on the Identification of the CF Gene: Recent Progress and New Research Strategies, held April 9-11, 1990, in Sestri Levante (Genoa), Italy

ISBN 978-1-4684-5936-4 ISBN 978-1-4684-5934-0 (eBook)

DOI 10.1007/ 978-1-4684-5934-0

(C) 1991 Springer Science+Business Media New York

Originally published by Plenum Press, New York in 1991

Softcover reprint of the hardcover 1st edition 1991

\section{All rights reserved}

No part of this book may be reproduced, stored in a retrieval system, or transmitted in any form or by any means, electronic, mechanical, photocopying, microfilming, recording, or otherwise, without written permission from the Publisher 
Seven months after the report of the cloning of the CF gene by three North American groups, a workshop scheduled before that report was held in Sestri Levante, a splendid city on the Ligurian coast. For three days almost 100 scientists from Europe and North America had the opportunity to discuss the perspectives and the new research strategies opened up by the cloning of the gene. The issue of publishing these proceedings was discussed at length among the invited speakers of the workshop and the prevailing opinion was that they would be worthwhile if accompanied by the transcripts of the discussions which followed each presentation. Thanks to the generous suppport of the Menarini Foundation, represented at the meeting by $\mathrm{Dr}$. Sergio Gorini, and thanks to the reviewing work done by the Chairpersons of each session, by many participants, by Dr. Donata Brugioni, by Mrs. Katherine Loparco and by my collaborators Drs. Marcella Devoto and Luis J.V. Galietta, that idea has generated this book, which should be a helpful tool at least for some years for all those interested in understanding how the CFTR gene works.

Prof. G. Romeo 


\section{CONTENTS}

Cystic Fibrosis - A strategy for the Future............ 1 R. Williamson

Molecular Genetics of Cystic Fibrosis.................. 9

L.-C. Tsui, J. Rommens, B. Kerem, R. Rozmahel,

J. Zielenski, D. Kennedy, D. Markiewicz,

N. Plavsic, J.-L. Chou, D. Bozon and M. Dobbs

The CF Gene Product as a Member of a Membrane

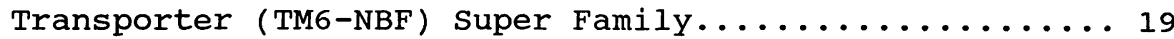

J.R. Riordan, N. Alon, Z. Grzelczak,

S. Dubel and S.-Z. Sun

Genetic Analysis of Cystic Fibrosis................. 31

X. Estivill, T. Casals and V. Nunes

Molecular and Genetic Analyses at the CF Locus........... 39

K.W. Klinger, P. Stanislovitis,

J. Merrill and G.T. Horn

Identification of Cystic Fibrosis Mutations............45

M. Dean, B. Gerrard, C. Stewart, L. Krueger,

D. Holsclaw, L. Quittell, V. Baranov,

N. Kapronov, M. Leppert, J. Amos and M. White

Mutation Analysis for Cystic Fibrosis in a

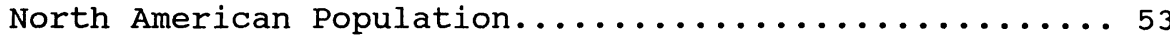

A.L. Beaudet, G.L. Feldman, K. Kobayashi,

W.K. Lemna, S.D. Fernbach, M.R. Knowles,

R.C. Boucher and W.E. O'Brien

Toward a Geographical History of the Predominant

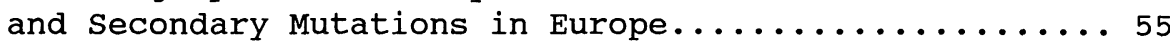

J.L. Serre

Origin and Diffusion of the Major

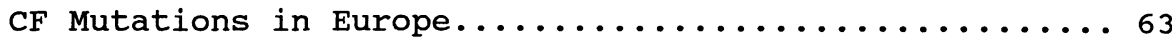

M. Devoto 
Present State of DNA-Diagnosis for Cystic Fibrosis

and Attitudes Concerning a Heterozygote

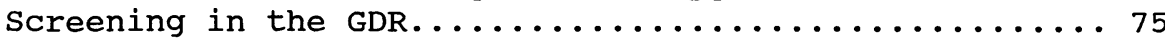

Ch. Coutelle, K. Grade, A. Speer, K. Will,

Chr. Gille, R. Szibor, J. Gedschold,

R. Brückner, V. Steinbicker, I. Bauer,

K. Giermann, H. Gorki, S. Meyer,

J. Brock, J. Hein and U. Brell

Pros and Cons of Neonatal Screening for

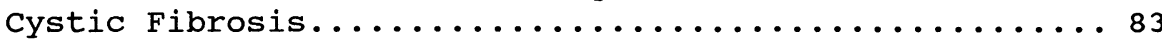

G.J. te Meerman and J.E. Dankert-Roelse

Genotype Phenotype Correlations in Cystic

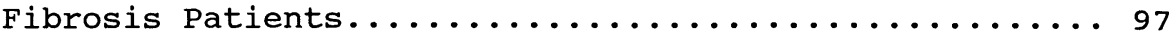

M. Stuhrmann, T. Dörk, M. Krawczak, M. Dueck,

U. Banholzer, J. Domagk, N. Hoffknecht,

H. -G. Posselt, A. Reis, M. Schlösser,

F. Trefz, M. Wagner, U. Wahn, B. Wulf,

J. Schmidtke, J. Reiss and B. Tümmler

Ion Transport in Normal and CF Airway Epithelia..........105

R.C. Boucher, T. Chinet, N. Willumsen,

M.R. Knowles and M.J. Stutts

Aerosolized Amiloride as Treatment of Cystic

Fibrosis Lung Disease: A Pilot Study..............119

M.R. Knowles, N.L. Church, W.E. Waltner,

J.R. Yankaskas, P. Gilligan, M. King,

L.J. Edwards, R.W. Helms and R.C. Boucher

Some Properties of Sodium and Chloride Channels

in Respiratory Epithelia of $\mathrm{CF}-$

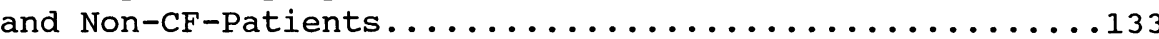

J. Disser, A. Hazama and E. Frömter

Roles of Ca and CAMP on Cl Channel Activity in

Cystic Fibrosis Sweat clear Cells as

Studied by Microsuperfusion and Cell

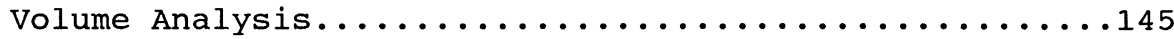

K. Sato, M. Ohtsuyama, Y. Suzuki, G. Samman,

K.T. Sato and F. Sato

Regulation of Absorption in the Human Sweat Duct..........159

P.M. Quinton and M.M. Reddy

Altered Biochemical Regulation of Secretion in

Cystic Fibrosis Epithelial Cells................173

M.A. McPherson, D.K. Shori, C. Lloyd Mills,

M.C. Goodchild and R.L. Dormer

Chloride Ion Transport in Transformed Normal and

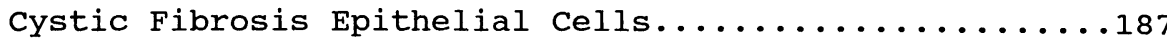

A.L. Cozens, M.J. Yezzi, L. Chin, E.M. Simon,

D.S. Friend and D.C. Gruenert 
Conductance Pathways Involved in Chloride

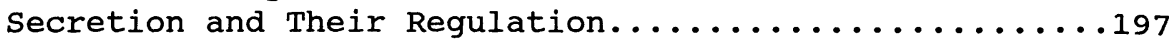

W.H. Cliff, R.T. Worrell, A.P. Morris and R.A. Frizzell

Regulation of Epithelial Chloride Channels: Roles of Protein Kinases and Arachidonic Acid...........209 T. -C. Hwang and W.B. Guggino

Cytosolic Inhibition and Excision Activation of Epithelial Chloride Channels..................225

K. Kunzelmann, M. Tilmann and R. Greger

Purification of the Epithelial Cl Channel..............235

Q. Al-Awqati, D. Landry, M. Akabas,

C. Redhead, A. Edelman and J. Edwards

Regulation of Expression of CFTR in Human

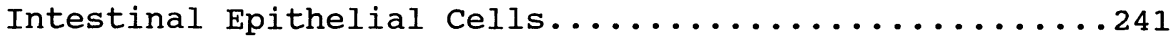

M. Buchwald, R. Sood and W. Auerbach

Cystic Fibrosis, the CFTR, and Rectifying

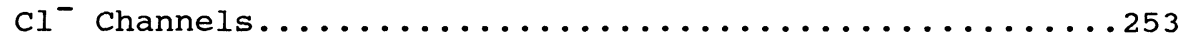

J.J. Wine, D.J. Brayden, G. Hagiwara,

M.E. Krouse, T.C. Law, U.J. Müller,

C.K. Solc, C.L. Ward, J.H. Widdicombe and Y. Xia

Regulation of Ion Conductance in Human

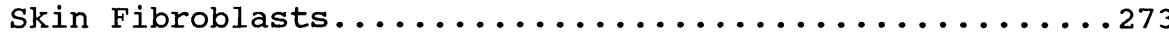

C.E. Bear

Chloride Transport in the Cystic Fibrosis Enterocyte......287

J. Bijman, H. Veeze, M. Kansen, B. Tilly,

B. Scholte, A. Hoogeveen, D. Halley,

M. Sinaasappel and $\mathrm{H}$. de Jonge

Chloride Transport Pathways in Human Keratinocytes........297

M. Rugolo, M. De Luca and T. Mastrocola

A Chloride Conductance Evoked by Hypotonic

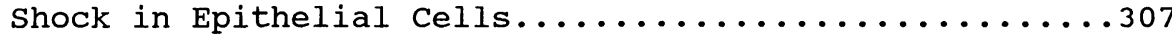

L.J.V. Galietta, V. Barone, D.C. Gruenert and G. Romeo

Regulation of Lymphocyte Chloride Channels.............. 319

P. Gardner, T. McDonald, I. Nishimoto, J. Wagner,

M. Schumann, J. Chen and H. Schulman

Guanine Nucleotide Binding Proteins Regulate

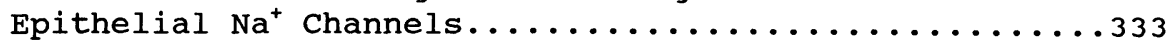

D.A. Ausiello, J.L. Stow, C.R. Patenaude and H.F. Cantiello 
Attitudes of Parents of Cystic Fibrosis Children Towards Neonatal Screening and Antenatal Diagnosis.........347

L.N. Al-Jader, M.C. Goodchild, H.C. Ryley and P.S. Harper

DNA Analysis in CF Families by Biotinylated Probes and

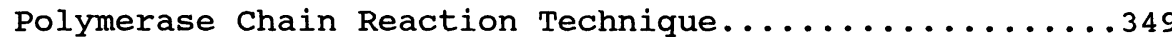

C. Camporese, L. Picci, N.A. Greggio, M. Abdol Mohammady, A. Barbato, L. Chiandetti, F. Anglani and F. Zacchello

Prevalence of the Major Mutation of the CF Gene

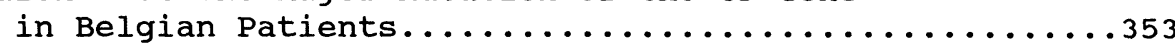

P. Cochaux, R. Van Geffel, D. Baran and G. Vassart

Cystic Fibrosis in the Sicilian Population: Linkage Disequilibrium and Prenatal Diagnosis by

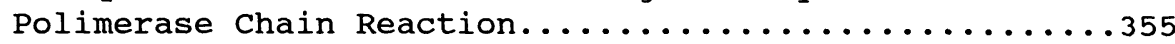

E. D'Alcamo, P. Sammarco, R. di Marzo, L. Iapichino, F. Pardo, A. Maggio, V. Balsamo and F. Caronia

Study of Reconstitution of the Rabbit Parotid

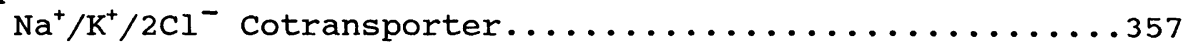

C. Ferri, M. Garnier and A. Corcelli

Human Placental Membrane Vesicles as Models for Investigation of Cystic Fibrosis.....................

A.K. Keenan, M. Cregg, D. Faller, C. Doolan, C. Somers, M.X. Fitzgerald and M.P. Ryan

The DeltaF508 Mutation in Israeli CF Families.................

I. Lerer, S. Cohen, M. Chemke, A. Friedmen and D. Abeliovich

The DeltaF508-Deletion in $99 \mathrm{CF}$ Patients

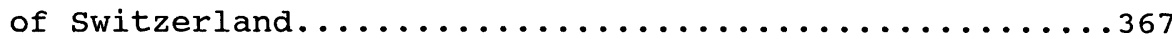

S. Liechti-Gallati, I. Parsai, R. Kraemer, A. Rudeberg, S. Braga and H. Moser

The Prevalence of the Deletion F508 in a Belgian

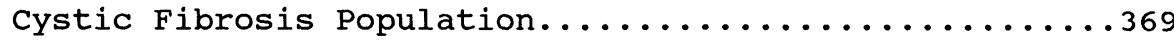

W. Lissens, M. Bonduelle, A. Malfroot, I. Dab and I. Liebaers

Cystic Fibrosis Delta F508 Mutation in a French

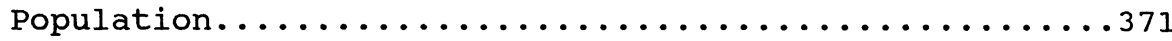

G. Lucotte and E. Barre

Frequency of the Delta-F508 Mutation and Flanking Marker Haplotypes at the Cystic Fibrosis

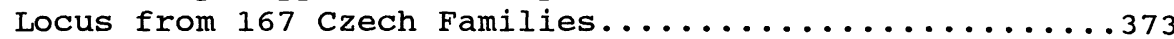

M. Macek, Jr., V. Vavrova, I. Boehm, M. Stuhrmann, A. Reis, M. Macek, R. Duspivova, E. Jelinkova, K. Sperling, M. Krawczak and J. Schmidtke 
The Response of Chloride Transport to Cyclic AMP, Calcium and Hypotonic Shock in Normal and cystic Fibrosis

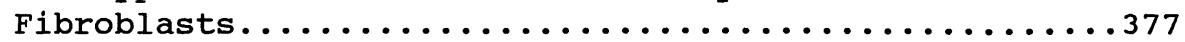

T. Mastrocola and M. Rugolo

2D-Electrophoresis of Mitochondrial Proteins from

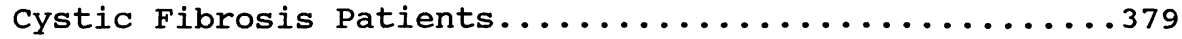

L. Picci, L. Brentegani, G. Mastella, E. Scarso,

P. Pizzochero, P. Mattiazzo, L. Chiandetti,

F. Anglani and F. Zacchello

Frequency of Cystic Fibrosis Mutations and Associated

Haplotype Distribution in Slovak CF Patients..........383

A. Puliti, J.J. Telleria orriols, R. Ronchetto,

L. Fenu, M. Devoto, G. Romeo, L. Kadasi,

J. Gecz and V. Ferak

Frequency of Cystic Fibrosis Mutations among

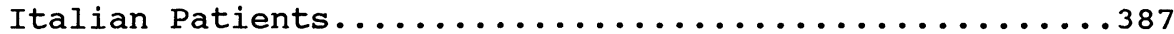

P. Ronchetto, L. Fenu, A. Puliti, M. Devoto,

L. Romano, G. Romeo, L. Cremonesi, P. Carrera,

L. Ruocco, M. Seia, S. Russo, A. Giunta and

M. Ferrari

Cultured Human Placental Trophoblasts as Models for

Investigating Defective Regulation of

Chloride Transport and Protein Secretion

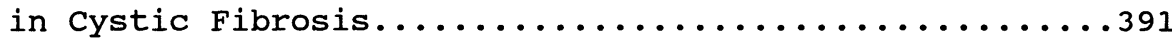

M.P. Ryan, C. Somers, M.X. Fitzgerald and

A.K. Keenan

A Deletion Mutation of the Cystic Fibrosis Transmembrane Conductance Regulator (CFTR) Locus: DeltaI507........393

M. Schwarz, C. Summers, L. Heptinstall,

C. Newton, A. Markham and M. Super

DNA Technology for Prenatal Diagnosis of Cystic Fibrosis

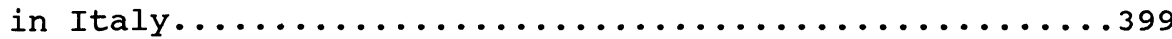

M. Seia, G. Cozzi, L. Sereni, M. Ferrari, L. Cremonesi, A.E. Covone, L. Fenu, P. Ronchetto, M. Devoto and G. Romeo

Incidence of Cystic Fibrosis at the Faroe Islands........403

N. Sørensen and M. Schwartz

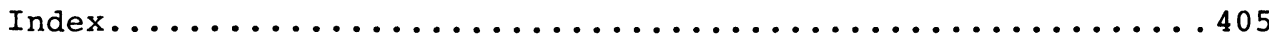

